\title{
Mercury-resistant rhizobial bacteria isolated from nodules of leguminous plants growing in high Hg-contaminated soils
}

\author{
Beatriz Ruiz-Díez • Miguel A. Quiñones • \\ Susana Fajardo • Miguel A. López • Pablo Higueras • \\ Mercedes Fernández-Pascual
}

Received: 29 July 2011 /Revised: 7 December 2011 / Accepted: 9 December 2011 / Published online: 14 January 2012

(C) Springer-Verlag 2012

\begin{abstract}
A survey of symbiotic bacteria from legumes grown in high mercury-contaminated soils (Almadén, Spain) was performed to produce a collection of rhizobia which could be well adapted to the environmental conditions of this region and be used for restoration practices. Nineteen $\mathrm{Hg}$-tolerant rhizobia were isolated from nodules of 11 legume species (of the genera Medicago, Trifolium, Vicia, Lupinus, Phaseolus, and Retama) and characterized. Based on their growth on Hg-supplemented media, the isolates were classified into three susceptibility groups. The minimum inhibitory concentrations (MICs) and the effective concentrations that produce $50 \%$ mortality identified the patterns of mercury tolerance and showed that 15 isolates were tolerant. The dynamics of cell growth during incubation with mercury showed that five isolates were unaffected by exposure to Hg concentrations under the MICs. Genetic analyses of the 16S rRNA gene assigned ten strains to Rhizobium leguminosarum, six to Ensifer medicae, two to Bradyrhizobium canariense, and one to Rhizobium radiobacter. Inoculation of host plants and analysis of the nodC
\end{abstract}

Electronic supplementary material The online version of this article (doi:10.1007/s00253-011-3832-z) contains supplementary material, which is available to authorized users.

B. Ruiz-Díez $(\bowtie) \cdot$ M. A. Quiñones $\cdot$ S. Fajardo $\cdot$

M. Fernández-Pascual

Instituto de Ciencias Agrarias (ICA),

Consejo Superior de Investigaciones Científicas (CSIC),

Serrano 115 dpdo,

28006 Madrid, Spain

e-mail: beatriz.ruiz@ica.csic.es

M. A. López · P. Higueras

Departamento de Ingeniería Geológica y Minera,

Escuela Universitaria Politécnica de Almadén,

Universidad de Castilla-La Mancha,

Ciudad Real, Spain genes revealed that most of them were symbiotically effective. Finally, three isolates were selected for bioremediation processes with restoration purposes on the basis of their levels of $\mathrm{Hg}$ tolerance, their response to high concentrations of this heavy metal, and their genetic affiliation and nodulation capacity.

Keywords Mercury-tolerant rhizobia $\cdot \mathrm{Hg}$-contaminated land · Rhizobia-legume symbiosis · Bioremediation

\section{Introduction}

The effects of soil contamination vary widely and directly affect water quality and the natural environment and therefore constitute a serious risk to human health and the environment. One of the biggest problems affecting terrestrial ecosystems is contamination with heavy metals, including mercury (Boening 2000). This is the case in the Almadén area (Spain), where the presence of the largest cinnabar $(\mathrm{HgS}$, the main ore of the element) deposit in the world and its exploitation for centuries for the production of mercury have caused the dispersion of the metal, and is recognized as one of the world's most mercurypolluted areas (Gray et al. 2004; Higueras et al. 2006; Molina et al. 2006; among others). Mercury is a highly polluting element, although the toxicity of its chemical species varies from relatively inert to highly toxic (Barkay et al. 2003). The toxicity and distribution of mercury in soil and its content in plants of Almadén were previously investigated (Millán et al. 2006; Molina et al. 2006; Moreno-Jiménez et al. 2006). However, up to date, it is not known how mercury contamination affects the diversity of soil microorganisms, which are essential for carrying out the biogeochemical cycles of the most important elements. Among soil microorganisms, the nitrogen-fixing bacteria are especially relevant in the nitrogen cycle. They 
associate with the roots of leguminous plants to form symbiotic structures called nodules in which atmospheric nitrogen is fixed. In this symbiosis, the plant receives nitrogen, while the bacterium receives carbohydrates and a favorable environment for nitrogen fixation. So far, 76 species in 13 genera of bacteria that can establish symbiosis with legumes have been identified (Weir 2010). Most of them are grouped in the rhizobial lineages, within the alpha-proteobacteria, comprised mainly by genera Rhizobium, Bradyrhizobium, Ensifer, Azorhizobium, and Mesorhizobium (generally denominated as "rhizobia"), although other alpha- and beta-proteobacteria capable of forming symbiosis with legumes have been reported (Weir 2010).

Legumes have proven their effectiveness in soil restoration and its preparation for colonization by other species, and because of this natural fertilizing function, they are regarded as pioneers (de Andrés et al. 2007; VillarSalvador et al. 2008). The optimal establishment of the legume requires the presence in the soil of symbiotic bacteria necessary for the fixation of atmospheric nitrogen. Therefore, soil restoration with legumes under limiting environmental conditions requires not only the selection of compatible rhizobia but also that these rhizobia are able to resist the stressing agent, in this case, the high mercury concentration in the soil.

By having resistance mechanisms which detoxify chemical forms of mercury, resistant bacteria may play an important role in its biogeochemistry in mercury-contaminated environments (Chadhain Ní et al. 2006). Thus, exploitation of bacterial mercury tolerance may potentially be used as a method of detoxifying mercury-contaminated sites (Barkay et al. 2003). Considering this fact and the important role of rhizobial-legume symbiosis for the soils, knowledge of the abundance, diversity, and activity of the mercury-tolerant members of the rhizobial communities become paramount. On the other hand, it is well known that heavy metals, and especially mercury, are toxic to bacteria even at low concentrations (Boening 2000), and to date, no mercurytolerant rhizobial strains have been identified. However, rhizobial strains tolerant to other heavy metals have been isolated from a variety of herbaceous (Carrasco et al. 2005; Pajuelo et al. 2008) and shrubby legumes (Ruiz-Díez et al. 2009). Different ecotypes of rhizobia can exhibit varying degrees of tolerance to stress by heavy metal contamination, so prior to the use of biotechnologies for inoculation with these microorganisms for the production of plants, it is necessary to establish a recruitment program of bacterial strains.

The aim of this work was to isolate and genotypically characterized the rhizobia associated with legumes from mercury-contaminated areas of South Central Spain to be used for restoration purposes. In order to select the highest tolerant isolates as specific inoculants for autochthonous legumes, their susceptibility to mercury has been analyzed.

\section{Materials and methods}

Bacterial isolates

Rhizobial isolates were obtained from root nodules of legumes grown in five soils from three areas of Almadén, Spain (Table 1). Physicochemical characteristics of the soils included a neutral $\mathrm{pH}$ (from 6.17 to 7.44 ) and three levels of mercury: San Quintín (212 $\mathrm{mg} \mathrm{Hg} \mathrm{kg}^{-1}$ ), Las Cuevas (970 mg Hg kg${ }^{-1}$ ), and Almadenejos (3,870 mg Hg kg${ }^{-1}$ ). The whole Almadén area comprised $300 \mathrm{~km}^{2}$. Isolation was performed from surface-sterilized nodules recovered directly from the legumes found in the sampling areas. The nodules of Lupinus albus and Phaseolus vulgaris were obtained by sowing their seeds (cultivars G1 and Planchada, respectively) in pots containing rhizospheric soils collected from the same natural sites. Briefly, nodules were surface-sterilized with ethanol 95\% (v/v) for $30 \mathrm{~s}$ and $\mathrm{HgCl}_{2} \quad 0.1 \%(\mathrm{v} / \mathrm{v})$ for $45 \mathrm{~s}$ and washed with sterilized, distilled water. Nodules were then cut, and a loopful of tissue containing bacteria was transferred to solid yeast extract mannitol (YM) medium (Vincent 1970). Single colonies were picked up and checked for purity by repeated streaking and by microscopic examination of cellular morphology. Isolates were routinely cultivated at $28^{\circ} \mathrm{C}$, maintained in YM agar (YMA) slants at $4{ }^{\circ} \mathrm{C}$ and in YM broth containing $20 \%(\mathrm{v} / \mathrm{v})$ glycerol at $-80{ }^{\circ} \mathrm{C}$. Randomly chosen nodules from plants of each area were examined for the existence of different bacteria. Previously characterized rhizobia isolated from the same legume species grown in noncontaminated areas of Central Spain were used as references (Table 1).

\section{Isolation of genomic DNA}

A loopful of each isolate was used to inoculate $20 \mathrm{ml}$ of YM broth. After incubation to saturation, the cells were harvested and washed twice with PBS, and DNA was isolated using the UltraClean TM Microbial DNA Isolation Kit (MOBIO). The concentration and integrity of DNA was analyzed with a spectrophotometer (Thermo Scientific) and by electrophoresis with $0.8 \%$ agarose gels and comparison with known amounts of phage lambda DNA (Sambrook et al. 1989). The DNA was further employed in all genetic tests.

\section{PCR amplifications and restriction analyses}

The primers fD1 and rP2 (Weisburg et al. 1991) were employed for 16S rDNA and NodCF and NodCI for nodC gene (Laguerre et al. 2001). All were synthesized by Genotek (Spain). The DNA which codified for 16S rRNA was amplified as previously described (Laguerre et al. 1994), with modifications according to Ruiz-Díez et al. (2009). The nodC PCR mixture was the same as described for PCR of $16 \mathrm{~S}$ rRNA 
Table 1 Strains isolated in the area of Almadén and rhizobia used as controls in these studies. Their provenance, original host, and genetic characterization based on chromosomal gene $16 \mathrm{~S}$ rRNA

\begin{tabular}{|c|c|c|c|c|}
\hline & \multirow[t]{2}{*}{ Geographical origin/coordinates ${ }^{\mathrm{a}}$} & \multirow[t]{2}{*}{ Original host } & \multicolumn{2}{|c|}{ Genetic characterization $^{\mathrm{b}}$} \\
\hline & & & ARDRA & 16S rRNA \\
\hline \multicolumn{5}{|l|}{ Isolate/species } \\
\hline R-7Q & San Quintín $/ 38^{\circ} 49.15^{\prime} \mathrm{N} 4^{\circ} 16.31^{\prime} \mathrm{W}$ & Retama sphaerocarpa & 1 & Rhizobium radiobacter \\
\hline L-7AH & $\begin{array}{l}\text { Almadenejos Hornos } / 38.1^{\circ} \\
44.3^{\prime} \mathrm{N} 4.1^{\circ} 42.5^{\prime} \mathrm{W}\end{array}$ & Lupinus albus & 2 & Bradyrhizobium canariense \\
\hline L-7Q & San Quintín & L. albus & 2 & B. canariense \\
\hline M-7AH & Almadenejos Hornos & Medicago sativa & 3 & Ensifer medicae \\
\hline M-7Q & San Quintín & Medicago polimorfa & 3 & E. medicae \\
\hline $\mathrm{M}-7 \mathrm{C}$ & Las Cuevas $/ 38^{\circ} 49.21^{\prime} \mathrm{N} 4^{\circ} 45.35^{\prime} \mathrm{W}$ & M. polimorfa & 3 & E. medicae \\
\hline J-7AH & Almadenejos Hornos & Phaseolus vulgaris & 3 & E. medicae \\
\hline J-7QC & $\begin{array}{l}\text { San Quintín Norte } / 38.1^{\circ} 49.2^{\prime} \mathrm{N} \\
4^{\circ} 16.4^{\prime} \mathrm{W}\end{array}$ & P. vulgaris & 3 & E. medicae \\
\hline $\mathrm{J}-7 \mathrm{C}$ & Las Cuevas & P. vulgaris & 3 & E. medicae \\
\hline $\mathrm{V}-7 \mathrm{~A}$ & Almadenejos $/ 38^{\circ} 44.27^{\prime} \mathrm{N} 4^{\circ} 42.44^{\prime} \mathrm{W}$ & Vicia sativa $\mathrm{L}$. & 4 & Rhizobium leguminosarum \\
\hline V-7Q & San Quintín & V. sativa $\mathrm{L}$. & 4 & R. leguminosarum \\
\hline V-7C & Las Cuevas & V. sativa $\mathrm{L}$. & 4 & R. leguminosarum \\
\hline TT-7A & Almadenejos & Trifolium tomentosum & 4 & R. leguminosarum \\
\hline TT-7AH & Almadenejos Hornos & T. tomentosum & 4 & R. leguminosarum \\
\hline TE-7AH & Almadenejos Hornos & Trifolium scabrum & 4 & R. leguminosarum \\
\hline T-7Q & San Quintín & Trifolium glomeratum & 4 & R. leguminosarum \\
\hline $\mathrm{TX}-7 \mathrm{C}$ & Las Cuevas & T. glomeratum & 4 & R. leguminosarum \\
\hline TT-7C & Las Cuevas & T. tomentosum & 4 & R. leguminosarum \\
\hline TS-7C & Las Cuevas & Trifolium repens & 4 & R. leguminosarum \\
\hline \multicolumn{5}{|l|}{ Reference strains } \\
\hline $\begin{array}{l}\text { Bradyrhizobium sp. } \\
\text { (Lupinus) CIFA ISLU-16 }\end{array}$ & Sevilla & Lupinus sp. & 2 & B. canariense \\
\hline B. canariense CCMA L-3 & La Higueruela $/ 40^{\circ} 4^{\prime} \mathrm{N} 4^{\circ} 26^{\prime} \mathrm{W}$ & L. albus $\mathrm{L}$. & 2 & B. canariense \\
\hline Ensifer meliloti CCMA ALF-3 & La Higueruela & M. sativa & 3 & E. meliloti \\
\hline $\begin{array}{l}\text { Rhizobium leguminosarum } \\
\text { bv. trifolii CCMA T-3 }\end{array}$ & La Higueruela & Trifolium subterraneum & 4 & R. leguminosarum \\
\hline Rhizobium gallicum CCMA J-2 & La Higueruela & P. vulgaris & 5 & R. gallicum \\
\hline
\end{tabular}

CIFA Centro de Investigación y Formación Agraria-Las Torres-Tomejil, Sevilla, CCMA Centro de Ciencias Mediambientales, CSIC

${ }^{a}$ Geographical locations from different areas of Almadén (Spain) and two agricultural lands of the La Higueruela Experimental Station (CCMA, CSIC), Santa Olalla, Toledo, Spain

${ }^{\mathrm{b}}$ ARDRA type obtained by analyses of 16S rRNA PCR amplified region digested with four endonucleases MspI, Hinfl, DdeI, and HhaI. Different numbers were assigned to represent each ARDRA group. 16S rRNA determined by comparison of the full nucleotide sequence with the GenBank database (http://www.ncbi.nlm.nih.gov/genbank/index.html)

gene, with the exception of the primers and $\mathrm{MgCl}_{2}$ whose final concentrations were $0.8 \mu \mathrm{M}$ and $2.5 \mathrm{mM}$, respectively. The amplifications were performed in a thermal cycler (Veriti 96 Well, Applied Biosystems) with the same temperature program as used by Ruiz-Díez et al. (2011). The PCR products were analyzed by electrophoresis on $0.8 \%$ agarose gels $(40 \mathrm{~V})$.

The restriction endonucleases MspI, Hinfl, DdeI, and HhaI (New England Biolabs) were used in separate digestion reactions with PCR-amplified 16S rRNA gene from all isolates listed in Table 1. A 15- $\mu$ l portion of amplification reactions was digested according to the manufacturer's recommendations, and restriction analyses of amplified $16 \mathrm{~S}$ rDNA (ARDRA) were performed as in Ruiz-Díez et al. (2009).

Determination of DNA sequences

Nearly $1,500 \mathrm{bp}$ of $16 \mathrm{~S}$ rRNA gene from the selected isolates (Fig. 1) were purified with the EZNA CYCLE-PURE kit (Omega), and approximately 930 bp of nodC from selected isolates (Fig. 2) were run on $0.8 \%$ agarose gels 


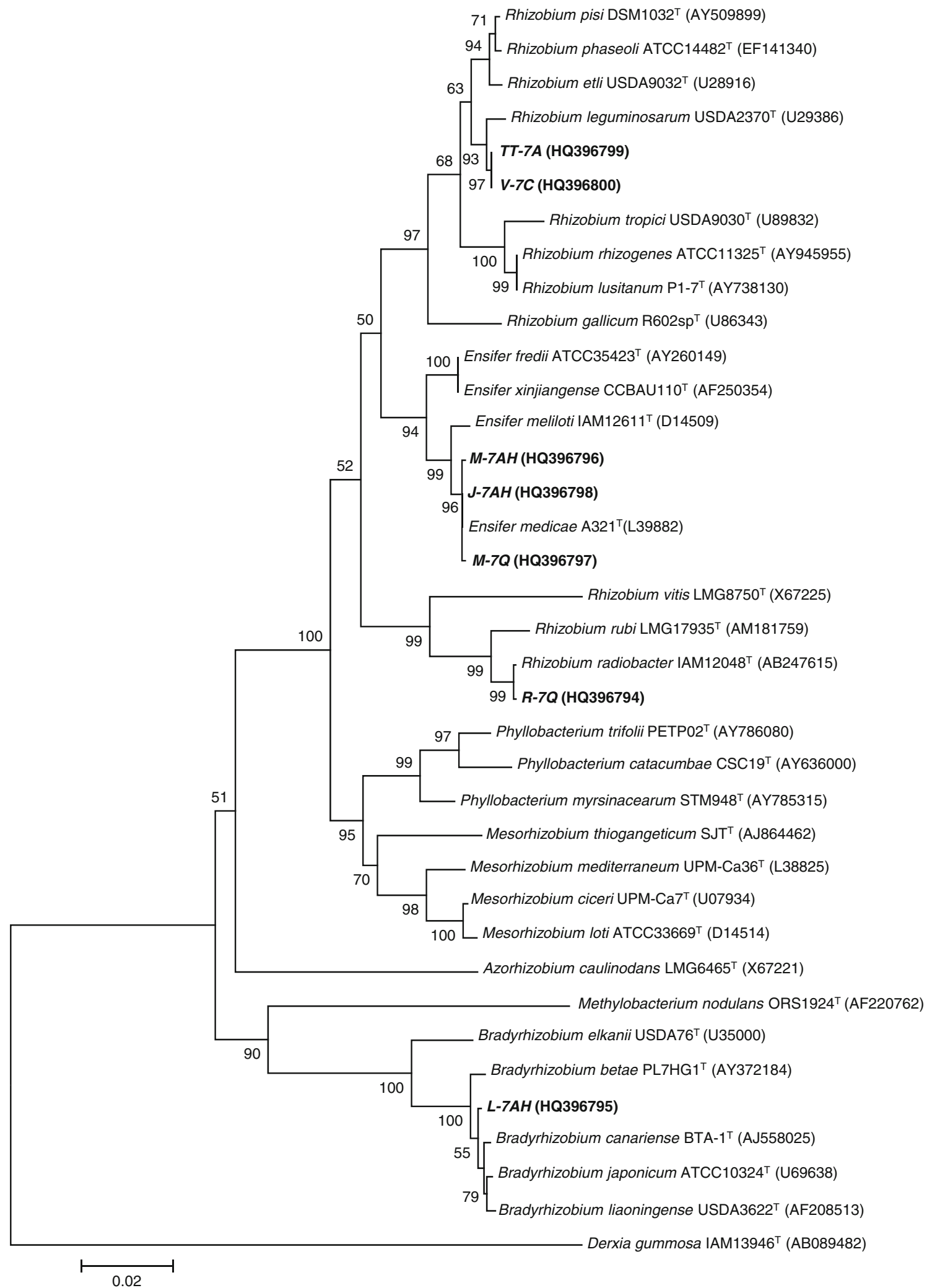

Fig. 1 Phylogenetic tree derived from neighbor-joining analysis of 1,420-bp-long 16S rRNA gene sequences from legume-nodulating isolates and representative type strains from the GenBank. Numbers above the branches are bootstrap values based on 1,000 replicates (only values of $50 \%$ or above are shown). Derxia gummosa was used as outgroup to root the tree (the bold letters indicate the sequences obtained in this study). Scale bar, $2 \mathrm{nt}$ substitution per $100 \mathrm{nt}$ 


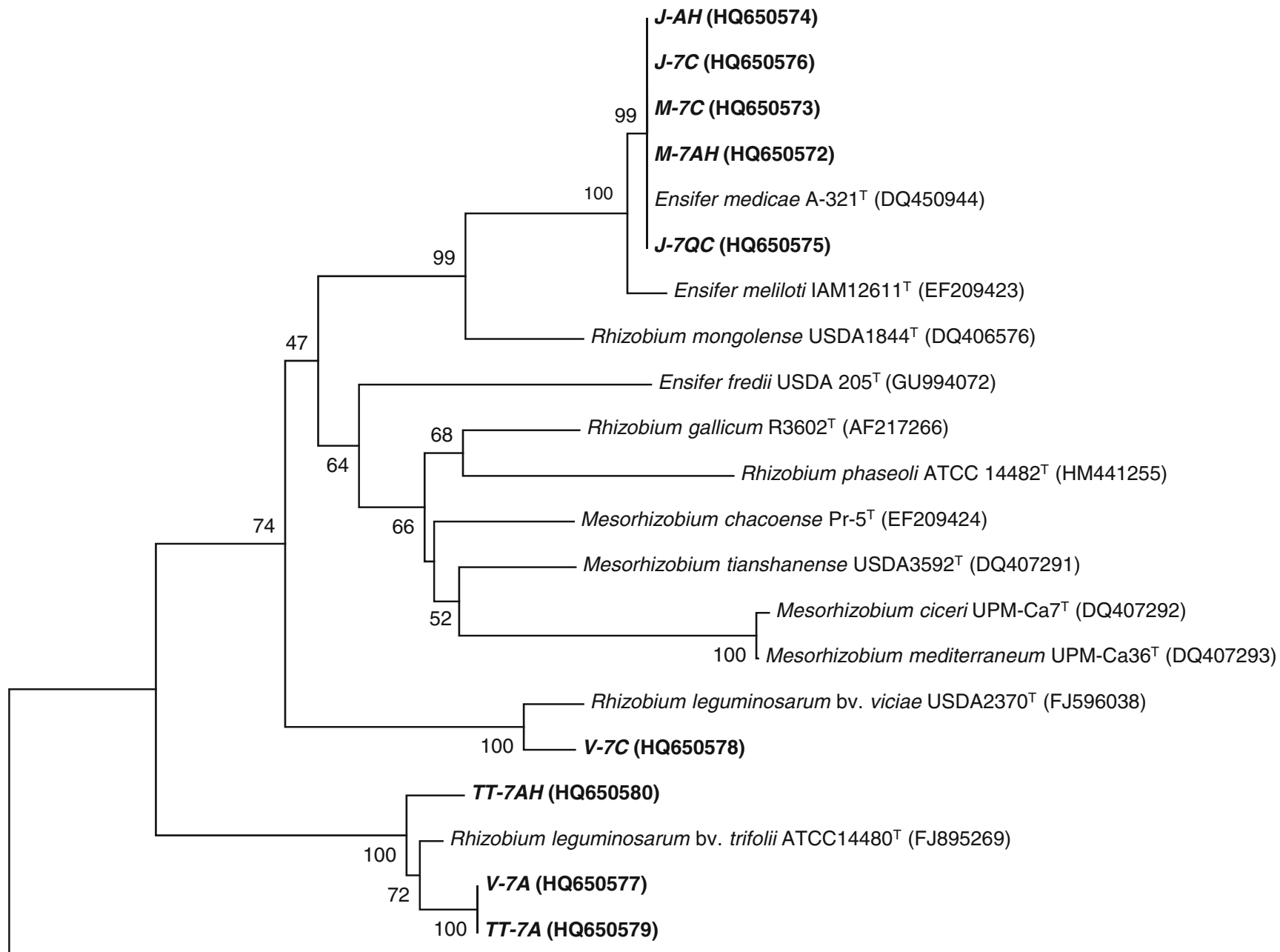

Azorhizobium caulinodans LGM6465 ${ }^{\top}$ (L18897)

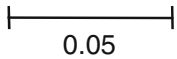

Fig. 2 Phylogenetic tree derived from neighbor-joining analysis of 933-bp-long nodC gene sequences from legume-nodulating isolates and representative related type strains from the GenBank. Numbers above the branches are bootstrap values (only values of $50 \%$ or above

and purified with illustraTM GFX PCR DNA and Gel Band Purification Kit (GE Healthcare). Sequences of PCR products were obtained with an ABI PRISM 3700 (Applied Biosystems) sequencer using the Taq Dyedeoxi Terminator cycle systems (Automatic Sequencing Service SAAD, CIB, CSIC, Madrid). The 16S rRNA gene was sequenced using each of the primers 1050R, 800R, $800 \mathrm{~F}$, and IRF1 (Lane 1991), which allowed for determination of almost the full $16 \mathrm{~S}$ rRNA gene sequence. The nodC PCR products were sequenced using the primers NodCF and NodCI. The sequences were determined by pairwise alignments employing the Clustal W program, and similarities were identified and analyzed by comparison with databases using the BLASTN program on the network service of GenBank (http://blast.ncbi.nlm.nih.gov/Blast.cgi). The percentage are shown). Azorhizobium caulinodans was used as outgroup to root the tree (bold letters indicate the sequences obtained in this study). Scale bar, $5 \mathrm{nt}$ substitution per $100 \mathrm{nt}$

values of homology with respect to the 16S rRNA gene were calculated with Clustal W multiple alignments (http:// www.npsa-pbil.ibcp.fr/). Phylogenetic analyses were performed using the MEGA program version 4 (Tamura et al. 2007). The phylogenetic trees were constructed using the neighbor-joining method (Saitou and Nei 1987) based on the two parameter distance model of Kimura. To assess the relative support for each clade, bootstrap values were calculated from 1,000 replicated analysis.

Nodulation tests

The nodulation ability of all isolates was checked by inoculating the host plants of origin as previously described (Vincent 1970). The seeds were surface sterilized by 
immersion in $\mathrm{HgCl}_{2} \quad 1 \%(\mathrm{v} / \mathrm{v})$ for 5 min and thoroughly washed with sterilized, distilled water. Retama sphaerocarpa seeds were first mechanically scarified. Subsequently, seeds were transferred to pots filled with sterile vermiculite and inoculated with $2 \mathrm{ml}$ of the bacterial inoculum (heavy suspension of the log-phase culture). Four replicates were established for each plant and treatment, incubated in a growth chamber $(15-\mathrm{h}$ photoperiod, $250 \mu \mathrm{mol}$ photon $\mathrm{m}^{-2} \mathrm{~s}^{-1}$, day/night temperature of $25 / 20{ }^{\circ} \mathrm{C}$ ) and watering with sterile nitrogen-free nutrient solution. Plants were harvested after 1 month of growth and checked for root nodules. Nitrogen fixation activity of plant-rhizobia symbioses was measured by the acetylene-reduction assay as previously described (Fernández-Pascual et al. 1988).

\section{Screening for mercury tolerance}

Mercury tolerance of the isolates and reference strains was determined in YM broth according to Ruiz-Díez et al. (2009). Mercury was assayed as mercury chloride $\left(\mathrm{HgCl}_{2}\right.$ analysis grade ACS, Merck), prepared in distilled water (MILLI-Ro Systems, Millipore), sterilized by membrane filtration (Millipore $0.22 \mu \mathrm{m}$ ), and added to the sterilized YM medium. The $\mathrm{HgCl}_{2}$ concentrations tested were $0,3,6$, $12.5,25,30,60,125$, and $250 \mu \mathrm{M}$. Briefly, $5 \mathrm{ml}$ of the medium was inoculated with $50 \mu \mathrm{l}$ of bacterial inoculum (suspension of the log-phase culture in $5 \mathrm{ml}$ of YM broth), reaching a final density of $10^{6} \mathrm{cells} / \mathrm{ml}$ and incubated at $28^{\circ} \mathrm{C}$ in a rotary shaker (100 rpm). The log-phase was previously determined by means of growth curves for each strain, and the log-phase was defined by a constant doubling time. Growth measurements were performed in the mid-log-phase by optical density determinations (absorbance at $680 \mathrm{~nm}$ ). The minimum inhibitory concentration (MIC) was defined as the lowest heavy-metal concentration that completely prevents visible growth. The experiments were repeated at least twice, with three replicates each time, and paired samples always gave the same end-point.

\section{Determination of exact range of toxicity}

Once the MIC was established, the rhizobial strains were cultured with serially increasing concentrations of $\mathrm{HgCl}_{2}$ up to the MIC in the log-phase as described previously. By plotting the relative growth rates (relative to the controls without mercury) against the concentrations of mercury, a direct correlation between the concentration of metal and its growth-inhibiting effect was observed, as previously described for other bacteria (OECD 2003), and a polynomial regression was performed (grade $2, R^{2} \approx 1$ ). From these regressions, the effective concentrations of mercury leading to $50 \%$ growth inhibition (EC50) were calculated by extrapolation and listed in Table 2.
Table 2 Patterns of resistance/tolerance to mercury, given as MIC, and toxicity, given as EC50, of the rhizobial strains isolated from nodules of leguminous plants in different soils of the area of Almadén and rhizobia used as controls (values obtained from three to six different replicates)

\begin{tabular}{|c|c|c|c|}
\hline & Species $^{\mathrm{a}}$ & $\begin{array}{l}\text { MIC } \\
(\mu \mathrm{M})^{b}\end{array}$ & $\begin{array}{l}\text { EC50 } \\
(\mu \mathrm{M})^{\mathrm{c}}\end{array}$ \\
\hline \multicolumn{4}{|l|}{ Strain } \\
\hline $\mathrm{R}-7 \mathrm{Q}$ & Rhizobium radiobacter & 30 & 16.69 \\
\hline L-7AH & Bradyrhizobium canariense & 12.5 & 4.39 \\
\hline L-7Q & B. canariense & $<3$ & $*$ \\
\hline M-7AH & Ensifer medicae & 6 & 2.82 \\
\hline M-7Q & E. medicae & 6 & 3.94 \\
\hline $\mathrm{M}-7 \mathrm{C}$ & E. medicae & 25 & 9.96 \\
\hline $\mathrm{J}-7 \mathrm{AH}$ & E. medicae & 12.5 & 5.83 \\
\hline $\mathrm{J}-7 \mathrm{QC}$ & E. medicae & $<3$ & $*$ \\
\hline $\mathrm{J}-7 \mathrm{C}$ & E. medicae & 25 & 9.36 \\
\hline $\mathrm{V}-7 \mathrm{~A}$ & $\begin{array}{l}\text { Rhizobium leguminosarum } \\
\text { bv. trifolii }\end{array}$ & 6 & 3.77 \\
\hline V-7Q & R. leguminosarum & 3 & 1.91 \\
\hline V-7C & R. leguminosarum bv. viceae & 6 & 4.54 \\
\hline TT-7A & R. leguminosarum bv. trifolii & 12.5 & 5.54 \\
\hline TT-7AH & R. leguminosarum bv. trifolii & 12.5 & 6.82 \\
\hline TE-7AH & R. leguminosarum & 12.5 & 6.21 \\
\hline T-7Q & R. leguminosarum & $<3$ & 1.92 \\
\hline TX-7C & R. leguminosarum & 12.5 & 6.85 \\
\hline TT-7C & R. leguminosarum & 12.5 & 7.32 \\
\hline TS-7C & R. leguminosarum & 12.5 & 5.11 \\
\hline \multicolumn{4}{|l|}{$\begin{array}{l}\text { Reference } \\
\text { strains }\end{array}$} \\
\hline ISLU-16 & Bradyrhizobium sp. (Lupinus) & $<3$ & $*$ \\
\hline L-3 & B. canariense & $<3$ & $*$ \\
\hline ALF-3 & Ensifer meliloti & $<3$ & $*$ \\
\hline $\mathrm{T}-3$ & R. leguminosarum bv. trifolii & $<3$ & $*$ \\
\hline $\mathrm{J}-2$ & Rhizobium gallicum & $<3$ & $*$ \\
\hline
\end{tabular}

Asterisks indicate that strains showed no growth at any of the concentrations tested

${ }^{\text {a }}$ Biovarieties determined by means of nodC phylogeny

${ }^{\mathrm{b}} \mathrm{MIC}$ is the lowest concentration of $\mathrm{HgCl}_{2}$ that completely prevents visible growth in comparison with the control without mercury

${ }^{\mathrm{c}}$ EC50 is the concentration of mercury that inhibits the exponential growth of bacteria by $50 \%$ compared to the control

Effect of mercury on the growth of rhizobial strains

Liquid cultures of $25 \mathrm{ml}$ of YM medium supplemented with $\mathrm{HgCl}_{2}$ at final concentrations of $0,3,6,12.5$, and $25 \mu \mathrm{M}$ (prepared as described previously) were inoculated with $250 \mu \mathrm{l}$ of a log-phase culture and grown at $28{ }^{\circ} \mathrm{C}$ for 7 days in a rotary shaker $(100 \mathrm{rpm})$. No volatilization of mercury or any measurable sorptions of metal on the glassware surface were detected under these conditions. Growth was monitored at 24-h intervals as the absorbance at $680 \mathrm{~nm}$ with a 
spectrophotometer (Spectronic 2000, Bausch $\alpha$ Lomb). Each strain was tested in triplicate at each point in the time series. A blank with the medium culture alone, with no added bacteria, was also analyzed.

Nucleotide sequence accession numbers

The sequences of the 16S rRNA genes were deposited in the GenBank database under accession numbers HQ396794396800 (provided in Fig. 1). The sequences of the nodC gene were also deposited in the GenBank (accession no. HQ 650572-650580 displayed in Fig. 2). The most promising rhizobial isolates obtained in this study (L-7AH, M-7C, and TT-7C) were deposited with the Colección Española de Cultivos Tipo (CECT, Valencia, Spain), accession numbers CECT 8017, 8018, and 8019, respectively.

\section{Results}

\section{Isolation of rhizobia}

Nineteen different rhizobial strains were isolated from nodules of 11 legumes grown in five soils with three different levels of mercury in the area of Almadén (Table 1). Isolates obtained from different nodules of the same host plant always rendered the same 16S genotype; consequently, one strain was chosen from each legume species. The examination of single colonies revealed that they could be identified as rhizobia. Most isolates were classified as fast growers, according to the classification of Odee et al. (1997), since their colonies were $>2 \mathrm{~mm}$ in diameter after 5 days in $\mathrm{YM}$ medium at $28^{\circ} \mathrm{C}$. Only strains L-7AH and L-7Q were classified as slow growers because their colonies were $\leq 1 \mathrm{~mm}$ in diameter after 7 days in YM medium at $28^{\circ} \mathrm{C}$.

\section{Genetic identification}

In order to obtain an initial genetic classification, the $16 \mathrm{~S}$ rRNA gene of all isolates (including references) was amplified, and the PCR products were digested with four endonucleases. Restriction analyses showed five genotypes (15 ), representing different combinations of patterns which were retrieved from all strains (Table 1). The 19 rootnodule isolates were grouped in four different rRNA genotypes (1-4), with group 4 including the majority of fastgrowing isolates (10) and exhibiting the same genotype pattern as Rhizobium leguminosarum CCMA T-3. The 16S rRNA gene is not able to discriminate the biovars. Slowgrowing isolates belonged to genotype 2 and were grouped with the Bradyrhizobium canariense CCMA L-3 reference strain. Genotype 3 included isolates from Medicago $\mathrm{sp}$. and Phaseolus vulgaris as well as the reference strain for Ensifer meliloti CCMA ALF-3. The isolate R-7Q (genotype 1) was separate from all strains including references. These preliminary ARDRAs allowed us to choose seven isolates which represented each genotype (and were also from different soils and plant hosts) for the determination of $16 \mathrm{~S}$ rRNA gene sequences to achieve the species affiliation, i.e., their genetic identity. The sequenced isolates from the same ARDRA genotype grouping showed identical or almost identical nucleotide composition. Sequence similarity searches (BLASTN) confirmed that all strains belonged to the Rhizobiales lineages within the $\alpha$-proteobacteria (Table 1). Consequently, a phylogenetic analysis was performed to assess the evolutionary relationships with related-type strains within the major Rhizobiales lineages (Fig. 1). The phylogenetic tree was divided into two major branches: One included the major genera Rhizobium, Ensifer, Phyllobacterium, and Mesorhizobium, whereas the second clade was mainly comprised of genera from the family Bradyrhizobiaceae. The two representative sequences of genotype 4 (TT-7A and V-7C) were grouped into a branch with the type strain of Rhizobium leguminosarum and presented 100\% homology with the closest relative Rhizobium leguminosarum strain ALM-2 (GenBank accession number DQ660316) and 99.5\% with Rhizobium leguminosarum type strain USDA2370. The strains M-7AH, J-7AH, and M-7Q (genotype 3) were included in the clade of genus Ensifer and closely related with Ensifer medicae (99.8\% homology with the closest E. medicae type strain A321). The isolate R-7Q was very close to Rhizobium radiobacter (formerly Agrobacterium tumefaciens), with $99.9 \%$ homology with respect to the closest relative Rhizobium radiobacter type strain IAM12048. Finally, isolate L-7AH stayed apart in the second main branch within the family Bradyrhizobiaceae, where it grouped with B. canariense (Fig. 1). This strain exhibited $100 \%$ homology with the closest $B$. canariense strain MCLA23 (GenBank no. EF694743) and $99.8 \%$ with $B$. canariense type strain BTA-1.

Analyses of nodulation capacity

The ability of the new rhizobial isolates to form symbioses with their own host plant was tested. The control uninoculated plants did not nodulate. All isolates nodulated their hostplant when they were reinoculated and had fixing nodules with the exception of R-7Q (identified as Rhizobium radiobacter).

The symbiosis-specific nodC gene, a common nod gene essential for nodulation in the majority of rhizobial species, was analyzed in selected strains of different rhizobial species (Fig. 2). This demonstrated their infective capacity for each soil type and plant host. R-7Q was also included in order to verify the results of the infectivity tests. The strains ascribed to $B$. canariense were excluded as a result of the 
difficulty in amplifying the nodC gene in Bradyrhizobium, probably due to low annealing of the primers. Bradyrhizobium nod genes are complex and have different regulation (Stacey 1995). A partial fragment of approximately $950 \mathrm{bp}$ of nodC gene was obtained for all strains tested. However, the isolate R-7Q did not amplify for the nodC gene. The nodC phylogenetic tree (Fig. 2) grouped the E. medicae strains in the Ensifer clade with the E. medicae reference strain, forming a robust phylogenetic group (bootstrap value of $99 \%$ ) which demonstrate a diverse range of host specificity for this rhizobial species. The strain V-7C was closely related to Rhizobium leguminosarum bv. viceae $(100 \%$ bootstrap), confirming the specificity of Vicia sativa for this biovar. Whereas the strains from Trifolium (TT-7AH and TT-7A) clustered with Rhizobium leguminosarum bv. trifolii in a well-defined branch (100\% bootstrap), the strain V-7A from $V$. sativa was surprisingly fitted in this clade.

\section{Evaluation of the susceptibility to mercury}

The discrimination and subsequent selection between mercury-tolerant and mercury-sensitive rhizobia require an indispensable and accurate cultivation-based approach before performing any other molecular approach.

The effect of $\mathrm{Hg}$ on growth of the isolates (Fig. 3), reported as a percentage growth relative to the controls, allowed us to identify the bacteria in relation to mercury tolerance and classify them into three susceptibility groups. The sensitive group (growths of $0-2 \%$ related to the control) included all reference strains employed in these assays (Table 2) and isolates L-7Q, J-7QC, V-7Q, and T-7Q. The MICs of this group were $\leq 3 \mu \mathrm{M}$ (MICs summarized in Table 2). The intermediate group integrated strains $\mathrm{M}-7 \mathrm{AH}, \mathrm{M}-7 \mathrm{Q}$, $\mathrm{V}-7 \mathrm{~A}$, and $\mathrm{V}-7 \mathrm{C}$, which showed similar moderate tolerance to metal concentrations (MICs of $6 \mu \mathrm{M}$ ). The remaining 11 isolates (the most numerous group) were classified as tolerant, with MICs of $\geq 12.5 \mu \mathrm{M}$. Although L-7AH and TS-7C were included in this group, they displayed a significant reduction of growth at $6 \mu \mathrm{M}$ (Fig. 3). In contrast, the strains $\mathrm{R}-7 \mathrm{Q}, \mathrm{M}-7 \mathrm{C}$, and $\mathrm{J}-7 \mathrm{C}$ were all extremely tolerant, and $\mathrm{R}-7 \mathrm{Q}$ had the highest tolerance. The determination of MICs allowed us to calculate the exact range of toxicity of each strain measured by EC50 (Table 2). The reference isolates did not grow at any of the concentrations assayed. As already observed for the MICs, each isolate showed a different degree of tolerance to mercury, and the EC50 values were of a similar order in each of the previously described tolerance groups. Again, M-7C, J-7C, and especially R-7Q presented the highest levels of tolerance compared to other strains.

Dynamics of cell growth during incubation with mercury

The dynamics of rhizobial growth at different incubation times were examined in all strains, and Fig. $4 a$, b shows the growth curves of six selected strains with a similar logarithmic-phase, representing different susceptibility groups. $\mathrm{M}-7 \mathrm{C}$ and $\mathrm{J}-7 \mathrm{C}$ represented the most tolerant, TE7AH and J-7AH represented tolerant, and $\mathrm{M} 7-\mathrm{AH}$ and $\mathrm{J}-$ $7 \mathrm{QC}$ represented the intermediate and sensitive isolates, respectively. The curves demonstrate that the most tolerant strains (M-7C and J-7C) grew at $12.5-\mu \mathrm{M} \mathrm{HgCl}_{2}$, the tolerant (TE-7AH and J-7AH) grew at $6 \mu \mathrm{M}$, the intermediate $\mathrm{M}-7 \mathrm{AH}$ displayed reduced growth at $3 \mu \mathrm{M}$, and the sensitive (J-7QC) displayed no growth at any concentration. In addition, the growth curves presented two different profiles: The majority of the isolates displayed less absorbance than the control at any of the concentrations tested (J-7C, TE7AH, M-7AH, and J-7QC shown in Fig. 4a, b), whereas isolates M-7C and J-7AH (shown in Fig. 4a, b) and R-7Q, L-7AH, and TT-7C (shown in Electronic Supplementary Material) exhibited similar growth rates as the control at
Fig. 3 Effect of $\mathrm{Hg}$ concentrations $(3,6,12.5$, and $25 \mu \mathrm{M})$ on the growth of the bacterial isolates. The isolates which did not grow at any of the concentrations tested (including control strains) are not shown in the bar diagram. Results are expressed as percentages relative to controls cells in media not supplemented with $\mathrm{HgCl}_{2}$. Data are means + $\mathrm{SE}$ from three to six replicate experiments

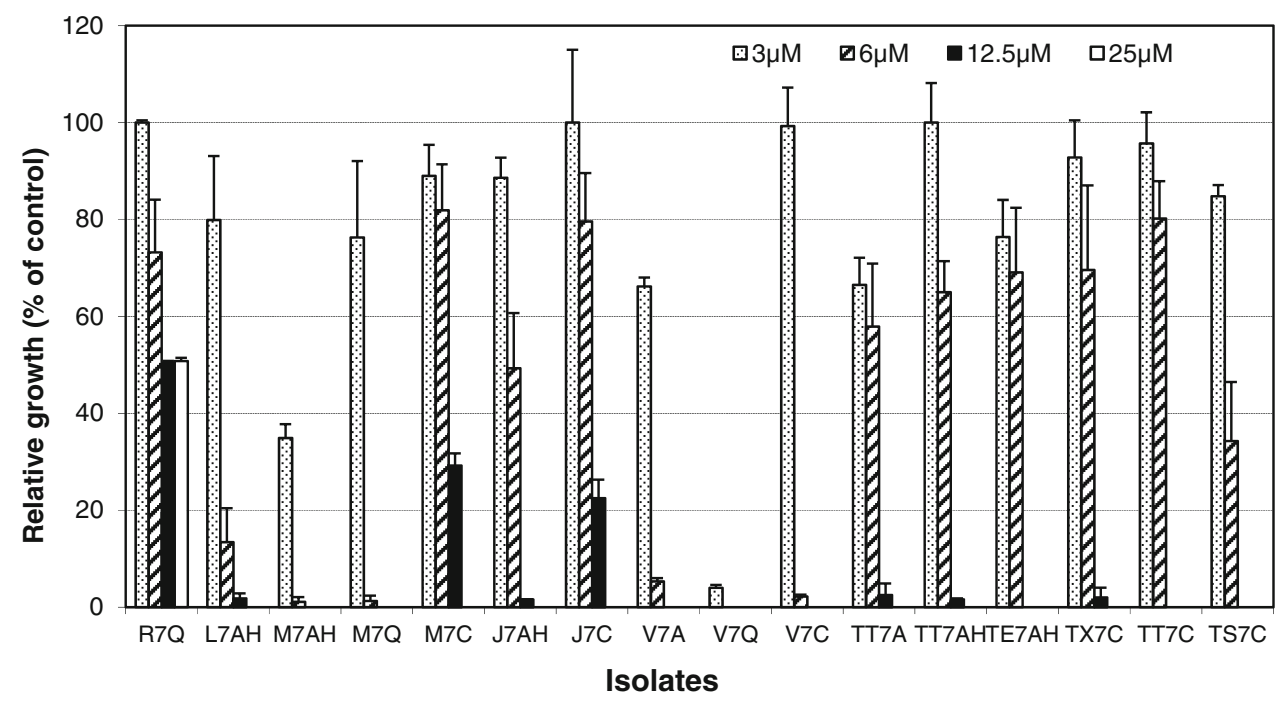


Fig. 4 Growth of rhizobia dependent on increasing mercury concentrations $(0,3,6$, 12.5 , and $25-\mu \mathrm{M} \mathrm{HgCl} 2)$. a Strains M-7C, TE-7AH, and M-7AH. b J-7C, J-7AH, and J-7QC. In each treatment, three flasks were used and sampled in the time series. Data shown are the means of three replicates. Growth curves for all 19 rhizobial strains isolated from the Almadén area, plus reference strains, are included in the Electronic Supplementary Material, with means \pm SE for each one

\section{a}

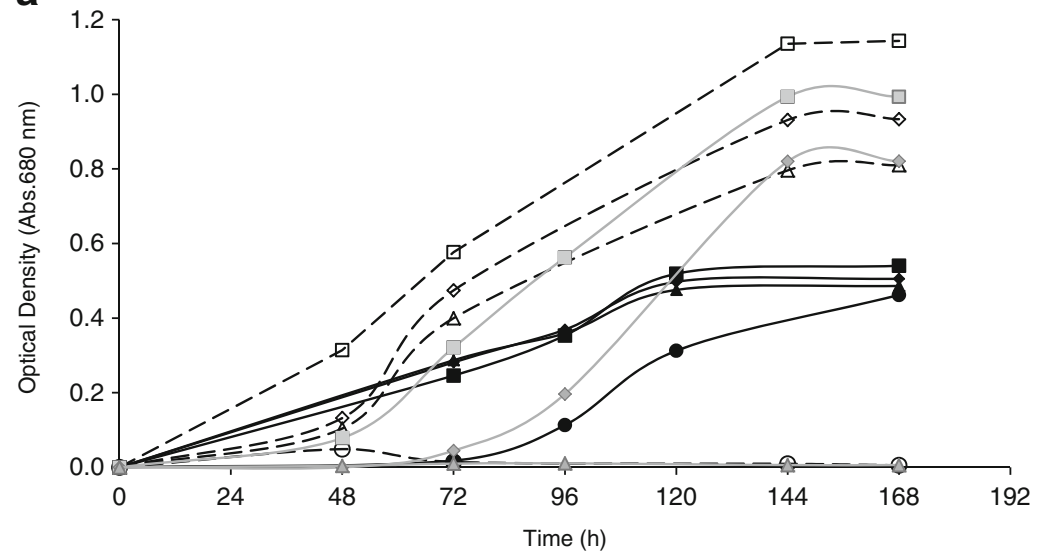

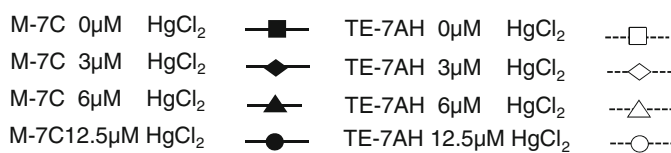

$\mathrm{M}-7 \mathrm{AH} 0 \mu \mathrm{M} \mathrm{HgCl}$ $\mathrm{M}-7 \mathrm{AH} 3 \mu \mathrm{M} \mathrm{HgCl}$ $\mathrm{M}-7 \mathrm{AH} 6 \mu \mathrm{MHgCl}$

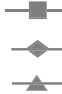

\section{b}
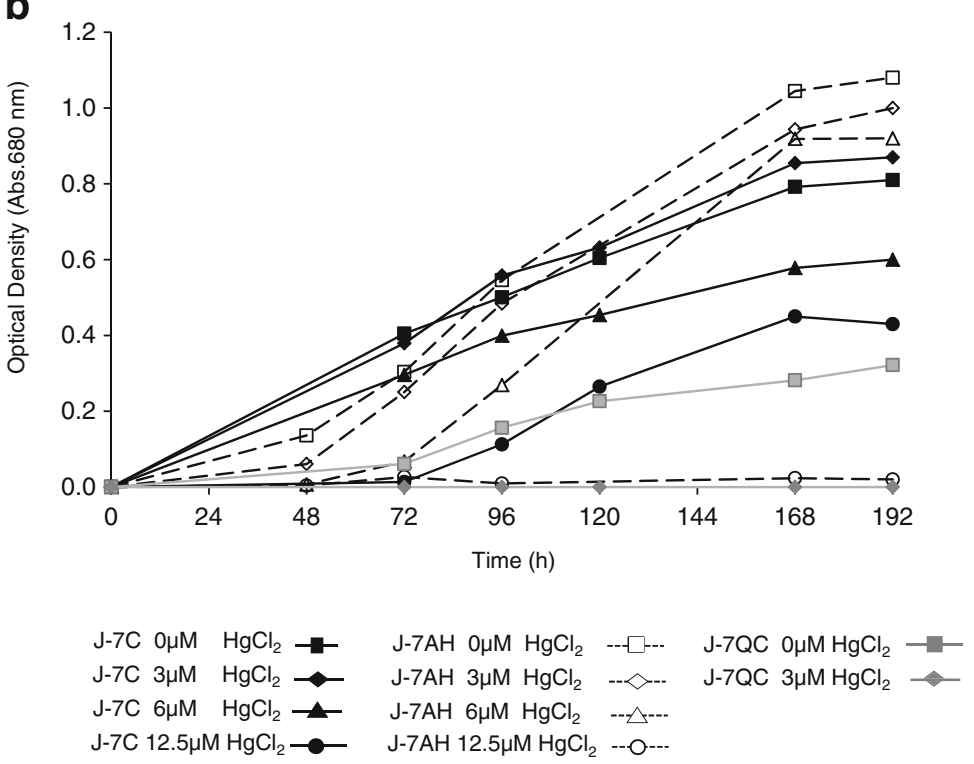

the $\mathrm{Hg}$ concentrations at which they grew and reached the same absorbance as the control in the stationary phase. Hence, five strains demonstrated the best response to the different concentrations of mercury and also displayed the highest EC50 values (Table 2) within each of the susceptibility groups which they represented. These strains were selected for the amplification of known genes of mercury resistance (Barkay et al. 2003), either merA (Liebert et al. 1997) or merR, merT, and the 5' end of merP (Abou-Shanab et al. 2007); however, our attempts repeatedly failed.

\section{Discussion}

Legume-rhizobia symbiosis biodiversity in areas contaminated with heavy metals has received little attention (Carrasco et al. 2005), and to our knowledge, this is the first study in mercury-contaminated land. Our surveys resulted in only a few species of leguminous plants being found in the five areas of Almadén, mostly belonging to Trifolium and Medicago. However, their relative abundance probably contributes to the distribution and diversity of rhizobial bacteria. Furthermore, we did not find differences in terms of the legume species growing in any of the areas. The ability of different herbaceous legumes to act as trap plants was tested with soils from the same areas, but only nodules from Phaseolus vulgaris and Lupinus albus were obtained.

The 16S RNA gene has demonstrated the existence of at least four different bacterial species within the 19 strains isolated, with most of them belonging to Rhizobium leguminosarum (10 isolates), but also to E. medicae (six isolates), $B$. canariense (two isolates), and Rhizobium radiobacter (one 
isolate). The large group of Rhizobium leguminosarum strains confirm our previous investigations with rhizobia nodulating agricultural legumes (Ruiz-Díez et al. 2011), which demonstrated the high success rate of this rhizobial species in Central Spain. The nodulation of $P$. vulgaris by $E$. medicae is atypical because this species usually nodulates legumes from the alfalfa cross-inoculation group, but reports of different species of Ensifer in association with P. vulgaris are increasing (e.g., Zurdo-Piñeiro et al. 2009). With respect to other species, as far as we know, this is the first time that Rhizobium radiobacter has been described in association with nodules of the leguminous shrub Retama sphaerocarpa. To summarize, the limited number of rhizobial species associated with these host plants was, in part, due to the small sampling area and its particular soil conditions in comparison with other studies. In general, the genetic diversity of mercury-acclimated bacterial communities is relatively low (Rasmussen and Sorensen 2001).

Analyses of nodulation ability by the rhizobial strains are necessary because increasing concentrations of heavy metals in the soil tend to reduce the nodulation of legumes (Zornoza et al. 2002; Pastor et al. 2003). In our experiments, all inoculated legumes had fixing nodules and amplified for the $\operatorname{nod} C$ gene, with the exception of those inoculated with R-7Q (identified as Rhizobium radiobacter, formerly Agrobacterium tumefaciens). These nodulation results could suggest that Rhizobium radiobacter colonized the Retama sphaerocarpa nodule just after its formation, forming part of the consortium of endophytic bacteria living in nodules (Muresu et al. 2008). This would agree with the fact that the former genus Agrobacterium generally does not form symbiotic root nodules unless they harbor a Sym plasmid or other transposable element with nodulation genes (Young et al. 2001). Rhizobium radiobacter isolates have also been found colonizing active nodules of $P$. vulgaris and modulating, either positively or negatively, the nodulation by native rhizobia (Mhamdi et al. 2005).

The phylogeny of nodC grouped the strains by their host plants. Only V-7A (from V. sativa) was clustered with Trifolium strains (TT-7AH and TT-7A). The three strains came from the same area with the highest mercury contamination (Almadenejos). Although nodC is employed as a molecular marker to identify the specific biovar (Moschetti et al. 2005), this symbiotic gene is carried on plasmids which can be interchanged between closely related rhizobial species (Franche et al. 2009). This lateral transfer of symbiotic genes between closely related rhizobial species isolated from very small areas with special characteristics has previously been documented (e.g., Hou et al. 2009). However, in general, the $\operatorname{nod} C$ analysis established that the capacity of soil rhizobia to form nodules is also determined by their host plants.

The effect of $\mathrm{Hg}$ on the growth of isolates allowed us to classify them into three susceptibility groups. The rhizobial MIC values for $\mathrm{Hg}$ were lower than the ones obtained for other bacteria (Abou-Shanab et al. 2007). In contrast to our isolates, their mercury-tolerant phenotype was mainly demonstrated with solid media, which, due to colonial growth, may not give an accurate estimate of resistance level. Besides, most of our isolates could be considered as tolerant to higher or lower degree since their MICs were significantly higher than the values for the reference strains growing in a nearby non$\mathrm{Hg}$-contaminated area. This phenotypic trait represents a very important finding because, to date, there are no previous reports of rhizobial strains tolerant to mercury isolated from Hg-contaminated soils. Isolate R-7Q from Retama sphaerocarpa was extremely tolerant to mercury, confirming our previous observations on the exceptional tolerance to natural stresses of rhizobia from shrubby legumes (Ruiz-Díez et al. 2009). The EC50 studies demonstrated the high toxicity of mercury: Half of the bacterial cells died at very low concentrations. In fact, this toxicity parameter is used as an indirect index of a pollutant's bioavailability for specific organisms and is commonly applied in ecotoxicity studies (OECD 2003). Furthermore, EC50 will allow us to define the concentrations of mercury to use in trials with these bacteria.

All strains classified as sensitive were isolated from legumes grown in the soil with low mercury concentrations (San Quintín). However, mercury MICs and EC50s of the other two susceptibility groups seemed to be independent of the soils in which the legumes grew and mostly came from either medium or high $\mathrm{Hg}$ levels, with the exceptions of R-7Q and M-7Q (also from San Quintín). The continuous exposure to mercury in the soils of origin, even at low levels, probably led to selection of tolerance among members of rhizobial group as reported for other gram-positive and gram-negative bacteria (Abou-Shanab et al. 2007; Rasmussen and Sorensen 2001). Until now, it has been impossible to establish a direct relationship between ecotoxicity parameters, such as EC50, and soil characteristics (Maliszewska-Kordybach et al. 2007). In addition, no correlations were found between any of the Hg-susceptibility groups and the rhizobial species or host plant, so the tolerance to $\mathrm{Hg}$ seems strain dependent, same with other heavy metals in different rhizobial symbioses (e.g., Hungria et al. 2001; Almeida Pereira et al. 2006; Ruiz-Díez et al. 2009). Our results also showed that the two tolerance indices considered (EC50 and MIC) can be successfully used for measuring $\mathrm{Hg}$ tolerance of rhizobia, as reported for other heavy metals and/or bacteria (e.g., Hungria et al. 2001; Pepi et al. 2009; Ruiz-Díez et al. 2009).

Measurement of the rate of processes at a large number of toxic concentrations is a good way to study the effects of a contaminant on a specific microorganism (Van Beelen and Doelman 1997). Our response curves showed that mercury inhibited growth to different degrees in all isolates and reflected two different responses: inhibition at any mercury concentration or only at the MICs. This second response could be explained from a toxicity point of view as a 
hormetic effect (Calabrese 2005), that is, a generally favorable biological response to low exposures of pollutant and inhibition at large doses. Strains that can survive better in soils containing high mercury levels can readily start their multiplication if mercury decreases, for example, after a volatilization or filtration event. Thus, the percentage of viable cells and the evolution of mercury tolerance are important parameters to be evaluated as they depend essentially on the concentration of mercury in the soil and the intrinsic capacity for mercury bioremediation and/or alleviation of each strain. However, our attempts to amplify the mercury resistance genes (Barkay et al. 2003) in these tolerant strains failed, possibly due to the utilization of other mechanisms to deal with $\mathrm{Hg}$ toxicity (Boening 2000). Consequently, this phenomenon, i.e., "phenotypic tolerance," could be accounted for by the mercury-mediated enrichment of subpopulations of rhizobial strains which are physiologically tolerant but genetically susceptible to mercury.

Considering all the susceptibility tests performed, the selection of strains with phenotypic traits of mercury tolerance comprises the species Rhizobium radiobacter (R-7Q), B. canariense (L-7AH), E. medicae (M-7C), and Rhizobium leguminosarum bv. trifolii (TT-7C). Although the most tolerant R-7Q did not nodulate, corroborating reports that resistant microorganisms often fail to perform specific ecological functions in polluted ecosystems (Van Beelen and Doelman 1997), this strain will be employed as a control of tolerance in future susceptibility studies. The isolates with high $\mathrm{Hg}$ tolerance and nodulation capacity will be utilized for analyzing the response of the symbioses to $\mathrm{Hg}$, first in a growth chamber and thereafter in Almadén soils.

This report reveals the existence of rhizobial bacteria able to survive in areas contaminated with mercury. Genetic analyses infer that the genetic diversity of rhizobia in this small area is a result of interactions among the specific environment/soil conditions, the host legumes, and bacterial genomic backgrounds. The phenotypic analyses indicate that most strains have unique properties of mercury tolerance, differing from strains isolated from near uncontaminated lands. This feature is important to allow these rhizobia to cope with the high mercury concentrations in Almadén soils. At present, we have selected the most promising strains (L-7AH, M-7C, and TT-7C) to be used with their host legume species for bioremediation processes on the basis of their levels of $\mathrm{Hg}$ tolerance and their response to its high concentrations, together with their genetic identification and nodulation capacity.

Acknowledgements This research was supported by the Junta de Comunidades de Castilla-La Mancha grants PII1I09-0142-4389 and POII10-0211-5015, Ministerio Español de Ciencia e Innovación AGL2009-10371, the Comunidad de Madrid S-0505/AMB/0321, and Fundación Areces. The authors would like to thank Dr. F Minchin for critical proofreading of the manuscript. BRD was supported by contracts of Junta de Comunidades de Castilla-La Mancha (POII090182-3834 and POII10-0211-5015).

\section{References}

Abou-Shanab RAI, Van Berkum P, Angle JS (2007) Heavy metal resistance and genotypic analysis of metal resistance genes in gram-positive and gram-negative bacteria present in $\mathrm{Ni}$-rich serpentine soil and in the rhizosphere of Alyssum murale. Chemosphere 68:360-367

Almeida Pereira SI, Gusmao Lima AI, Almeida Paula Figueira EM (2006) Screening possible mechanisms mediating cadmium resistance in Rhizobium leguminosarum bv. viceae isolated from contaminated Portuguese soils. Microb Ecol 52:176-18

Barkay T, Miller SM, Summers AO (2003) Bacterial mercury resistance from atoms to ecosystems. FEMS Microbiol Rev 27:355384

Boening DW (2000) Ecological effects, transport, and fate of mercury: a general review. Chemosphere 40:1335-1351

Calabrese EJ (2005) Paradigm lost, paradigm found: the re-emergence of hormesis as a fundamental dose response model in the toxicological sciences. Environ Pollut 138:378-411

Carrasco JA, Armario P, Pajuelo E, Burgos A, Caviedes MA, López R, Chamber MA, Palomares AJ (2005) Isolation and characterisation of symbiotically effective Rhizobium resistant to arsenic and heavy metals after the toxic spill at the Aznalcóllar pyrite mine. Soil Biol Biochem 37:1131-1140

Chadhain Ní SM, Schaefer JK, Crane S, Zylstra GJ, Barkay T (2006) Analysis of mercuric reductase (merA) gene diversity in an anaerobic mercury-contaminated sediment enrichment. Environ Microbiol 8(10):1746-1752

De Andrés F, Walter I, Tenorio JL (2007) Revegetation of abandoned agricultural land amended with biosolids. Sci Total Environ 378:81-83

Fernández-Pascual M, de Felipe MR, Serra T, Pozuelo JM (1988) Effects of cianazine and Linuron on chloroplast development, nodule activity and protein metabolism in Lupinus albus L. J Plant Physiol 133:288-294

Franche C, Lindstrom K, Elmerich C (2009) Nitrogen-fixing bacteria associated with leguminous and non-leguminous plants. Plant Soil 321:35-59

Gray JE, Hines ME, Higueras PL, Adatto I, Lasorsa BK (2004) Mercury speciation and microbial transformations in mine wastes, stream sediments, and surface waters at the Almadén Mining District, Spain. Environ Sci Technol 38:4285-4292

Higueras P, Oyarzun R, Lillo J, Sánchez-Hernández JC, Molina JA, Esbrí JM, Lorenzo S (2006) The Almadén district (Spain): anatomy of one of the world's largest Hg-contaminated sites. Sci Total Environ 356:112-124

Hou BC, Wang ET, Li Y, Jia RZ, Chen WF, Man CX, Sui XH, Chen WX (2009) Rhizobial resource associated with epidemic legumes in Tibet. Microb Ecol 57:69-81

Hungria M, Chueir LMO, Coca RG, Megías M (2001) Preliminary characterization of fast growing rhizobial strains isolated from soybean nodules in Brazil. Soil Biol Biochem 33:1349-1361

Laguerre G, Allard MR, Revoy F, Amarger N (1994) Rapid identification of rhizobia by restriction fragment length polymorphism analysis of PCR-amplified 16S rRNA genes. Appl Environ Microbiol 60:56-63

Laguerre G, Nour SM, Macheret V, Sanjuan J, Drouin P, Amarger N (2001) Classification of rhizobia based on nodC and nifH gene analysis reveals a close phylogenetic relationship among Phaseolus vulgaris symbionts. Microbiology 147:981-993 
Lane DJ (1991) 16S/23S rRNA sequencing. In: Strackebrandt E, Goodfellow M (eds) Nucleic acid techniques in bacterial systematics. Wiley, Chichester, pp 115-175

Liebert CA, Wireman J, Smith T, Summers AO (1997) Phylogeny of mercury resistance (mer) operons of gram-negative bacteria isolated from the fecal flora of primates. Appl Environ Microbiol 63:1066-1076

Maliszewska-Kordybach B, Klimkowicz-Pawlas A, Smrezak B (2007) Ecotoxic effect of phenanthrene on nitrifying bacteria in soils of different properties. J Environ Qual 16:1635-1645

Mhamdi R, Mrabet M, Laguerre G, Tiwari R, Aouani ME (2005) Colonization of Phaseolus vulgaris nodules by Agrobacteriumlike strains. Can J Microbiol 51:105-111

Millán R, Gamarra R, Schmid T, Sierra MJ, Quejido AJ, Sánchez DM, Cardona AI, Fernández M, Vera R (2006) Mercury content in vegetation and soils of the Almadén mining area (Spain). Sci Total Environ 368:79-87

Molina JA, Oyarzun R, Esbrí JM, Higueras P (2006) Mercury accumulation in soils and plants in the Almadén mining district, Spain: one of the most contaminated sites on Earth. Environ Geochem Health 28:487-498

Moreno-Jiménez E, Gamarra R, Carpena-Ruiz RO, Millán R, Peñalosa JM, Esteban E (2006) Mercury bioaccumulation and phytotoxicity in two wild plant species of Almadén area. Chemosphere 63:1969-1973

Moschetti G, Peluso AL, Protopapa A, Anastasio M, Pepe O, Defez R (2005) Use of nodulation pattern, stress tolerance, nodC gene amplification, RAPD-PCR and RFLP-16S rDNA analysis to discriminate genotypes of Rhizobium leguminosarum biovar viceae. Syst Appl Microbiol 28:619-631

Muresu R, Polone E, Sulas L, Baldan B, Tondello A, Delogu G, Cappuccinelli P, Alberghini S, Benhizia Y, Benhizia H, Benguedouar A, Mori B, Calamassi R, Dazzo FB, Squartini A (2008) Coexistence of predominantly nonculturable rhizobia with diverse, endophytic bacterial taxa within nodules of wild legumes. FEMS Microbiol Ecol 63:383-400

Odee DW, Sutherland JM, Makatiani ET, McInroy SG, Sprent JI (1997) Phenotypic characteristics and composition of rhizobia associated with woody legumes growing in diverse Kenyan conditions. Plant Soil 188:165-175

OECD (Organization for Economic Co-Operation and Development) (2003) Draft guidance document on the statistical analysis of ecotoxicity data. OECD, Paris

Pajuelo E, Dary M, Palomares AJ, Rodriguez-Llorente ID, Carrasco JA, Chamber MA (2008) Biorhizoremediation of heavy metals toxicity using rhizobium-legume symbioses. In: Dakora FD, Chimphango SBM, Valentine AJ, Elmeric C, Newton WE (eds) Biological nitrogen fixation: towards poverty alleviation through sustainable agriculture, vol 42, Book Series: Current plant science and biotechnology in agriculture. Springer, Dordrecht, Netherlands, pp 101-104

Pastor J, Hernández AJ, Prieto N, Fernández-Pascual M (2003) Accumulating behaviour of Lupinus albus L. growing in a normal and a decalcified calcic luvisol polluted with Zn. J Plant Physiol 160:1455-1463

Pepi M, Lobianco A, Renzi M, Perra G, Bernardini E, Marvasi M, Gasperini S, Volterrani M, Franchi E, Heipieper HJ, Focardi SE (2009) Two naphthalene degrading bacteria belonging to the genera Paenibacillus and Pseudomonas isolated from a highly polluted lagoon perform different sensitivities to the organic and heavy metal contaminants. Extremophiles 13:839-848

Rasmussen LD, Sorensen S (2001) Effect of mercury contamination on the culturable heterotrophic, functional and genetic diversity of the bacterial community in soil. FEMS Microbiol Ecol 36:1-9

Ruiz-Díez B, Fajardo S, Puertas-Mejía MA, de Felipe MR, FernándezPascual M (2009) Stress tolerance, genetic analysis and symbiotic properties of root-nodulating bacteria isolated from Mediterranean leguminous shrubs in Central Spain. Arch Microbiol 191:35-46

Ruiz-Díez B, Fajardo S, de Felipe MR, Fernandez-Pascual M (2011) The characterization of rhizobia from legumes of agronomic interest grown in semi-arid areas of Central Spain relates genetic differences to soil properties. J Basic Microbiol. doi:10.1002/ jobm. 201100058

Saitou N, Nei M (1987) The neighbour-joining method: a new method for reconstructing phylogenetic trees. Mol Biol Evol 4:406-425

Sambrook J, Fritsch EF, Maniatis T (eds) (1989) Molecular cloning: a laboratory manual, 2nd edn. Cold Spring Harbor Laboratory Press, Cold Spring Harbor, New York

Stacey G (1995) Bradyrhizobium japonicum nodulation genetics. FEMS Microbiol Lett 127:1-9

Tamura K, Dudley J, Nei M, Kumar S (2007) MEGA4: Molecular Evolutionary Genetics Analysis (MEGA) software version 4.0. Mol Biol Evol 24:1596-1599

Van Beelen P, Doelman P (1997) Significance and application of microbial toxicity tests in assessing ecotoxicological risks of contaminants in soil and sediment. Chemosphere 34:455-499

Villar-Salvador P, Valladares F, Domínguez-Lerena S, Ruiz-Díez B, Fernandez-Pascual M, Delgado AC, Peñuelas J (2008) Functional traits related to seedling performance in a Mediterranean leguminous shrub: insights from a provenance, fertilization, and rhizobial inoculation study. Environ Exp Bot 64:145-154

Vincent JM (1970) A manual for the practical study of root nodule bacteria. Blackwell Scientific, Oxford

Weir BS (2010) The current taxonomy of rhizobia. New Zealand rhizobia website, http://www.rhizobia.co.nz/taxonomy/rhizobia. html. Last update: 21 st October (2010)

Weisburg WG, Barns SM, Pelletier DA, Lane DJ (1991) 16S ribosomal DNA amplification for phylogenetic study. J Bacteriol 173:697703

Young JM, Kuykendall LD, Martinez-Romero E, Kerr A, Sawada H (2001) A revision of Rhizobium Frank (1889), with emended description of the genus, and the inclusion of all species of Agrobacterium Conn (1492) and Allorhizobium undicola de Lajudie et al. (1988) as new combinations: Rhizobium radiobacter, $R$. rhizogenes, $R$. rubi, $R$. undicola and $R$. vitis. Int J Syst Evol Microbiol 51:89-103

Zornoza P, Vázquez S, Esteban E, Fernández-Pascual M, Carpena R (2002) Cd-stress in nodulated white lupin: strategies to avoid toxicity. Plant Physiol Biochem 40:1003-1009

Zurdo-Piñeiro JL, García-Fraile P, Rivas R, Peix A, León-Barrios M, Willems A, Mateos P, Martínez-Molina FE, Velázquez E, Van Berkum P (2009) Rhizobia from Lanzarote, the Canary Islands, that nodulate Phaseolus vulgaris have characteristics in common with Sinorhizobium meliloti isolates from Mainland Spain. Appl Environ Microbiol 75:2354-2359 